\title{
An Empirical Study on Patient Delight and the Impact of Human and Non-Human Factors of Service Quality on Patient Satisfaction in Private Hospitals
}

\author{
K. Vidhya ${ }^{1}$, Dr. C. Samudhra Rajakumar ${ }^{2}$, Dr. K. Tamizhjyothi ${ }^{3}$ \\ ${ }^{1}$ Research Scholar, Bharathiar School of Management \& Entrepreneur Development, Bharathiar University, \\ Coimbatore, India. \\ ${ }^{2}$ Professor, DDE, Department of Management Studies, Annamalai University, Chidambaram, India. \\ ${ }^{3}$ Assistant Professor, DDE, Department of Management Studies, Annamalai University, Chidambaram.
}

\begin{abstract}
Health, one of the Fundamental Human Rights has been accepted in the Indian Constitution. Today the healthcare industry has emerged as one of the most challenging sectors as well as one of the largest service sector industries in India. Patient perceived service quality become the prominent aspect to choose between hospitals. The purpose of this paper is to evaluate patient perceived service quality in Indian hospitals. Further the impact of the dimensions on patient satisfaction and patient delight is examined. A questionnaire was administered to the in-patients and multiple regression analysis has been used to examine the impact of the dimensions on patient satisfaction and patient delight. Findings emphasize eight distinct dimensions of patient perceived service quality and the impact on patient satisfaction and patient delight. A positive and significant relationship with patient satisfaction and patient delight has been found, except two dimensions. The results of this study are limited, as they are based on Indian hospitals. The contribution of this research paper, incorporate patient delight in health care sector. In addition, this paper highlights the importance of emotional attachment for patient satisfaction and patient delight in health care.
\end{abstract}

Keywords: Emotional attachment, health care, patient delight, patient satisfaction, service quality.

\section{Introduction}

Nowadays, service industries are dominant in developed countries. Service sectors have accounted for approximately two-thirds of the total worldwide GNP at the beginning of the twenty-first century. Even though services are among the fastest growing sector in emerging countries, health care service is not considered as a business, but a welfare service: offered by the public sector. Still this sector needs extreme concentration on improvement with respect to customer needs (Shabbir et.al, 2010). Now a day it is hard to see healthy people around us. Disease, doctor and medicine become the part of life. Not only the diseased, even the healthy people visit doctor for a checkup, since prevention is better than cure. It's because of people move far away from natural life, changing food habit, mechanical life, pollution, and western culture. The medicine taken by the patient can affect the internal system and organs of the body and creates side effects too. People are dying daily as a result of uncontrollable events such as automobile accidents or chronic disease, but deaths due to medical error are preventable, and a nation's healthcare system must reach the point where no patient will ever be the victim of a medical error (Radhika et al., 2007). Having a strong healthcare system in place will enable healthcare providers to deliver better quality and value to patients (Radhika et al., 2007). Developing countries like India, needs basic education and healthcare to every citizen to strengthen their basement to grow and compete in the technical world. As India stands in second position in world (1210 million) population (2011 census), it is difficult to cater its public healthcare service to satisfy and delight the patients. At this point the private sector takes responsibility to care and do the service in healthcare as much as possible. Moreover it is not simple since many factors have to contribute a lot similar to the support from government and the public. Besides service quality has become an important corporate strategy for health care organizations (Dagger et.al, 2007).

\section{Research gap}

Majority of the study have been done in the context of identification of service quality dimension and the impact of factors affecting patient satisfaction in health care service. The construct of health care service quality has different factor structures in different studies. However, understanding not only the dimensions of healthcare services but also the extent of their influence of patient delight gives valuable insights to hospital managers and administrators. Service practitioners believe that in order to retain customers they must go beyond satisfaction to delight. Indeed, they see delight/disgust as different concepts than satisfaction/dissatisfaction.

There is an extensive literature on customer satisfaction than customer delight. Delight is an emerging 
concept in product and service when quality concepts put forth its importance through customization and relationship management. Customer satisfaction can be measured through various tools like SERVQUAL, SERVPERF and so on.

In delight concepts there are some researcher tried to measure and distinguish satisfaction and delight. The researchers derived few models in various service sectors although, no research has been found in the area of health care service sector. Unfortunately; there is no commonly accepted scale to measure customer delight. Hence this paper took an attempt to fill the gap in the Indian context, which has a multicultural base. It is possible to delight the customers towards a product or service which is commercial. But it is not easy to delight the patients in healthcare, which is a basic need. In an age of increasing competition, merely 'satisfying' customers is not enough; rather 'delighting' customers has become essential for long-term success.

\section{Objective}

The main objective of this research is to identify the human and non-human healthcare services quality factors and to find out which factor that influence patient delight in private hospitals.

\section{Review of literature}

Based on an extensive review of literature on service quality, the critical dimensions of patient perceived health-care quality dimensions have been identified. With these dimensions, an instrument measuring the patient's viewpoint of health care quality has been administered. From the literature the researcher identified seven primary dimensions grouped as human factor and non-human factor. The following dimensions are used in healthcare instrument. The three primary dimensions, Interpersonal attitude, Professional treatment and Sense of well being come under human factor. The other four primary dimensions, Physical evidence, Administrative procedures, Fee and Reputation grouped under non-human factor. Along with primary dimensions Personal behaviour, Communication, Professional Treatment, Treatment Outcomes, Reliability, Trust, Infrastructure, Tangibles, Safety measures, Geographic convenience, Social responsibility and Image as sub dimensions are used in this research.

\section{Human Factor}

Human factor consists of interpersonal attitude, professional treatment and sense of well being as primary dimensions along with personal behaviour, communication, Treatment Outcomes, Reliability and Trust as sub dimensions.

\section{Interpersonal attitude}

The first service quality primary dimension interpersonal attitude consists of personal behavior and communication as sub dimensions. Interpersonal attitude refers the relationship and the interaction between the service provider and the user during service delivery. Koch, et.al (1992) identified a variable 'staff involvement' has gained significantly high priority in their study. In another study, Kara et.al, (2005) concluded that attitude; trust on nurses and behaviour of the employees to the patients and their families are very important intangible factors that can affect service quality. Dagger et.al, (2007) found interaction has a significant, positive and large effect on perceptions of interpersonal quality. To improve patients' perceptions of the hospital, friendly and courteous staff viz., doctors, nurses, paramedical and support staff are needed (Padma et.al 2009).

\section{Professional Quality}

The second service quality primary dimension named as Professional quality includes professional treatment and treatment outcomes as sub dimensions. Professional quality denotes the service providers' competence and the treatment consequences. Studies revealed that technical quality was the most important factor in both private and public hospitals (Gronroos, 1982; Rose, et al. 2004). Dagger et.al, (2007) found that technical qualities have greatest impact on service quality perception. They suggest that through empowering customers' knowledge of treatment process and improving customers' perceptions of service providers' expertise technical service quality can be improved. Added to that physicians should be involved continuous learning programmes to improve their knowledge professionally (Rohini and Mahadevappa, 2006).

\section{Sense of Well Being}

The third service quality primary dimension identified as sense of well being which consists of reliability and trust as sub dimensions. Sense of well being represents that how far the service provider consistent to the patient in delivering service. Ramsaran-Fowder (2008) derived an instrument called "PRIVHEALTHQUAL" and identified a new dimension as "Fair and Equitable Treatment / Reliability" is the most important variable which impact on private health service quality. Akdag and Zineldin (2010) identified 
sense of well being that patient's feel in the hospital as the third most important factor of patient's perception of quality in healthcare where this has a negative image in Turkey.

\section{Non-human factor}

Non human factor consists of physical evidence, administrative procedure, fee and reputation as primary dimensions and infrastructure, tangibles, safety measures, geographic convenience, image and social responsibility as sub dimensions.

\section{Physical Evidence}

The fourth service quality primary dimension identified as Physical evidence. It contains infrastructure, tangibles, safety measures and geographic convenience as sub dimensions. Physical evidence indicates the visual things bounded with core service which appears in the environment. Reidenbach and sandifer-smallwood (1990) found "physical appearance" which means perception of hospital room and staff. Oswald et.al (1998) found that the patients' primary concern was the quality of infrastructure and interaction like food served and ability of sleeping accommodations for patients' family members in hospitals (Akdag and Zineldin, 2010).

Duggirala et.al (2008) and Padma et.al, (2009) stated that the kind of safety measures to safeguard the patients physically, such as patients' allergy or reaction to certain drugs, hygiene maintained, handrails in aisles, ramps designed for wheelchairs, can influence the quality perception of patients.

\section{Administrative Process}

The fifth service quality primary dimension identified as administrative process. It comprises admission process; discharge processes and waiting time carry over by staff. It signifies the work carried over from admission to discharge to avail the core service while the fair time taken into consideration. Dagger et.al, (2007) found administrative qualities have the greatest impact on service quality perceptions. Operation, timeliness and support dimensions all had significant effect on perceptions of administrative quality. Processes like ease of getting appointments, ambulance service, simplicity of admission and discharge, all are essential in ensuring a hassle-free treatment to patients (Padma et.al, 2009).

\section{Fee}

The sixth service quality primary dimension identified as fee. It involve cost that incurred by patients for the treatment. Low affordability and very limited third party payment strongly reinforces 'cost' as an important dimension of care quality (William and Sahu). Stock and McDermott (2011) found increased length of stay, increased patient volume, and educational mission were associated with higher cost per patient.

Mortality performance was associated with lower cost per patient. Chandra et.al (2011) studied two specific costs associated with medical supply and medical billing processes. They identified significant waste exists across the entire medical supply process that needs to be eliminated. It is assumed that satisfied customers will purchase more frequently and in greater amounts, that will decrease transaction costs, and that new customers will be attracted through lower costs and hence lower prices (Yang, 2011).

\section{Reputation.}

The seventh service quality primary dimension identified as reputation. It consists of social responsibility and image as sub dimensions. It refers the commitment towards the well being of society where the organization is situated, thereby mutually benefitted. Rohini and Mahadevappa (2006), identified, a spacious visitor lounge which would add to the hospital's reputation. Customers might perceive higher service quality if the business satisfied their self-actualization needs, such as charity work, promoting environmental awareness (Chiu and Lin, 2004). Therefore, it is suggested that if a hospital provides free treatment to economically downtrodden people, it would boost the hospital's image and thereby improve patients' perceptions of service quality (Padma et.al, 2009). Caruana (2002) and Hong and Goo (2004) stated that reputation enjoyed by a service firm influenced its customer satisfaction. Hence, in healthcare services, the reputation of hospital has to be considered as an element of service quality (Padma et.al 2009).

\section{Emotional attachment}

The eighth service quality dimension identified as emotional attachment. It refers the poignant relationship between the service provider and the user which is related to core service with significant consideration of attributes and evaluation. There is often a formal, long-term relationship between doctor and patient, with the doctor having a significant discretion in meeting customer needs, and evaluation is largely based on credence attributes (Bitner et.al, 1990). Service quality is primarily a cognitive, left-brained, evaluative, objective concept, while satisfaction is combination of an affective, right-brained, feelings-based and subjective component with a cognitive, left-brained, evaluative, objective component. (Malhotra et.al, 1994).

Likewise hospitalization is more than just a physical experience (Tomes and Ng, Stephen, 1995). It 
includes ongoing doctor-patient relationships which place more emphasis on feelings and emotions rather than cognitive elements, as would be the case in an analysis of a discrete exchange (Duggirala et.al, 2008).

\section{Patient Satisfaction}

The health care system is fundamentally a service based industry, and customer satisfaction is an important characteristic (Shabbir et.al 2010). Oswald et.al (1998) studied quality dimension "human performance" found significantly related to customer (patient) satisfaction. Added to that, observers (visitors) were found more likely to be satisfied with hospital services than consumers. Marley, et,al (2004) found that the ability of patients to evaluate process quality than clinical quality has its own impact on patient satisfaction.

Duggirala et.al (2008); Shabbir et.al (2010) identified that service quality has significant impact on patient satisfaction. Hence customer satisfaction can be achieved through employee perceptions when they were empowered in a positive environment to deliver high - quality customer service (Scotti, et.al, (2007).

\section{Delight}

In a review of the services literature, a growing body of literature exists on consumer satisfaction and dissatisfaction, little academic work empirically on delight. Kumar and Iyer, (2001) found service provider's interpersonal behavior will be a better discriminator between customer satisfaction and customer delight than aspects related to the firm's service characteristics. Evans and Burns (2007) performed a qualitative study and proposed that the delighter items fell in three groups such as feature, delivery and wholes. Added to that, performance inferences, product characterizations, and references to self were considered as product as a whole, benefits and quality inferences were responses to all three types of delighter. The author suggested, to delight consumers, a firm must offer unexpected value in a positive way like provide valued supporting services unrelated to the core service. Whereas C.C.Yang (2011) developed and presented Customer Delight Barometer (CDB) using Kano model to identify critical delight-driving attributes and satisfaction-driving attributes. He found communication and attitude along with empathy are the two attributes found as delight drivers for the customers. Hence managers need to establish which quality attributes can evoke delight among patients. To achieve delight in healthcare, hospitals must improve all aspects continuously in its operation.

\section{Methodology}

To examine the patients' perception of quality in health care, a comprehensive survey of theoretical and empirical research in this area has been carried out. The literature revealed key constructs of quality in health care as viewed by the patients. Keeping this in mind, a questionnaire is framed by incorporating the critical dimensions of healthcare service quality. Ten variables have been taken for the study wherein three belong to human factors namely interpersonal attitude (12 items), professional treatment ( 9 items) and sense of well being (4 items); four belongs to non-human factors namely physical evidence (21 items), administrative procedures (10 items), fee (3 items) and reputation (3 items), one for patient satisfaction (4 items), one for emotional attachment (5 items) and finally the dependent variable patient delight (5 items). A preliminary version of the questionnaire was first developed in English. The items were translated next in the local language (Tamil), agreed that the two version were comparable. The study population was defined as in-patients who had admitted in the private hospitals for treatment at Puducherry, India. All constructs were measured on five point Likert scale in a structured format with the verbal statements 'strongly disagree' and 'strongly agree' anchor to the numerals 1 and 5 respectively. The scale size of the hospitals (bed capacity) varies introducing heterogeneity on the data (Priporas et.al, 2008). The convenience sampling method was followed for the study as other methods were less feasible in a hospital context (Jayesh \& Renuka, 2010). The questionnaire has been administered to 237 in-patients (including attendants) who have been under treatment at the hospital. Data were gathered over a 6 months period.

\section{Analysis and results}

Table .1: Regression analysis - Influence of human factors on patient satisfaction -Model Summary

\begin{tabular}{|c|c|c|c|c|}
\hline $\mathrm{R}$ & R Square & $\begin{array}{c}\text { Adjusted R } \\
\text { Square }\end{array}$ & F & Sig. \\
\hline $.663(\mathrm{a})$ & .237 & .436 & 114.188 & $<0.001$ \\
\hline
\end{tabular}

a Predictors: (Constant), Interpersonal attitude, Professional quality, Sense of Well being b Dependent Variable: Patient Satisfaction 
Coefficients(a)

\begin{tabular}{|l|r|r|r|r|r|}
\hline & \multicolumn{2}{|c|}{ Unstandardized Coefficients } & $\begin{array}{r}\text { Standardized } \\
\text { Coefficients }\end{array}$ & \multirow{2}{*}{ Sig. } \\
\cline { 2 - 4 } & $\mathrm{B}$ & Std. Error & Beta & & \\
\hline (Constant) & .581 & .165 & & 3.512 & .000 \\
\hline Interpersonal attitude & .311 & .060 & .265 & 5.156 & .000 \\
\hline Professional quality & .103 & .065 & .097 & 1.598 & .111 \\
\hline Sense of Well being & .396 & .063 & .372 & 6.275 & .000 \\
\hline
\end{tabular}

a Dependent Variable: Patient Satisfaction

Multiple regression analysis is carried out to examine how human factors such as interpersonal attitude, professional quality and sense of well being influence patient satisfaction. Table. 1 summarizes the results of regression analysis. The adjusted $R^{2}$ value is found to be 0.436 which means that 43.6 percent of the variation of dependent variable patient satisfaction is influenced by independent variables (human factors), and the $\mathrm{R}^{2}$ value is also statistically significant $(\mathrm{F}=114.188 ; \mathrm{p}<0.001)$. It is evident from ' $\mathrm{t}$ ' value, among the independent variables, sense of well being is the most influencing variable for patient satisfaction $(t=6.275 ; p<0.001)$, which is followed by interpersonal attitude $(\mathrm{t}=5.156 ; \mathrm{p}<0.001)$. Professional quality is least influencing variable and insignificant to patient satisfaction $(\mathrm{t}=1.598)$.

Table .2: Regression analysis - Influence of non-human factors on patient satisfaction

\begin{tabular}{|c|c|c|c|c|}
\hline \multicolumn{5}{|c|}{ Model Summary } \\
\hline $\mathrm{R}$ & R Square & $\begin{array}{l}\text { Adjusted R } \\
\text { Square }\end{array}$ & $\mathrm{F}$ & Sig. \\
\hline $.771(\mathrm{a})$ & .595 & .591 & 159.608 & $<0.001$ \\
\hline
\end{tabular}

a Predictors: (Constant), , Physical Evidence, Administrative procedure, Reputation, Fee

b Dependent Variable: Patient Satisfaction

Coefficients(a)

\begin{tabular}{|l|r|r|r|r|r|}
\hline & \multicolumn{2}{|c|}{ Unstandardized Coefficients } & $\begin{array}{r}\text { Standardized } \\
\text { Coefficients }\end{array}$ & \multirow{2}{*}{ Sig. } \\
\cline { 2 - 4 } & $\mathrm{B}$ & Std. Error & Beta & & .492 \\
\hline (Constant) & -.105 & .152 & & .688 & .000 \\
\hline Physical Evidence & .301 & .056 & .235 & 5.411 & .000 \\
\hline Administrative procedure & .494 & .062 & .387 & 7.967 & .334 \\
\hline Fee & -.029 & .030 & -.035 & -.966 & .000 \\
\hline Reputation & .279 & .042 & .278 & 6.578 & .048 \\
\hline
\end{tabular}

a Dependent Variable: Patient Satisfaction

From the results presented in the table. 2 it is clear that 59.1 percent of the variation of patient satisfaction is influenced by physical evidence, administrative procedure, fee and reputation, and the $\mathrm{R}^{2}$ value is also statistically significant $(\mathrm{F}=159.608 ; \mathrm{p}<0.001)$. Furthermore, based on the results of regression coefficients, except 'Fee' $(\mathrm{t}=-0.966)$ the remaining three factors (administrative procedure, reputation and physical evidence) indicated statistically significant unique relationship with patient satisfaction.

Table. 3: Regression analysis- Influence of emotional attachment on patient delight

Model Summary

\begin{tabular}{|c|r|c|c|c|}
\hline $\mathrm{R}$ & R Square & $\begin{array}{c}\text { Adjusted R } \\
\text { Square }\end{array}$ & F & Sig. \\
\hline $.803(\mathrm{a})$ & .645 & .641 & 157.545 & $<0.001$ \\
\hline
\end{tabular}

a Predictors: (Constant), Happy to take treatment with this doctor, Trust my doctors, Sentiments, Confident that doctor cure my disease, Come for hospital because of doctors' midas touch

b Dependent Variable: Patient Delight 


\section{Coefficients(a)}

\begin{tabular}{|c|c|c|c|c|c|}
\hline & \multicolumn{2}{|c|}{ Unstandardized Coefficients } & \multirow{2}{*}{$\begin{array}{r}\begin{array}{r}\text { Standardized } \\
\text { Coefficients }\end{array} \\
\text { Beta }\end{array}$} & \multirow{2}{*}{$\mathrm{t}$} & \multirow{2}{*}{ Sig. } \\
\hline & B & Std. Error & & & \\
\hline (Constant) & 1.033 & .099 & & 10.414 & .000 \\
\hline $\begin{array}{l}\text { Come to hospital } \\
\text { because of doctors' } \\
\text { midas touch }\end{array}$ & .250 & .026 & .403 & 9.494 & .000 \\
\hline Sentiments & -.072 & .029 & -.103 & -2.466 & .014 \\
\hline $\begin{array}{l}\text { Confident that doctor } \\
\text { cure my disease }\end{array}$ & .193 & .029 & .265 & 6.581 & .000 \\
\hline Trust my doctors & .251 & .025 & .365 & 10.135 & .000 \\
\hline $\begin{array}{l}\text { Happy to take } \\
\text { treatment with this } \\
\text { doctor }\end{array}$ & .083 & .024 & .137 & 3.440 & .001 \\
\hline
\end{tabular}

a Dependent Variable: Patient Delight

The results of multiple regression analysis as shown in table. 3 explain that the regression model was statistically significant $(\mathrm{F}=157.545 ; \mathrm{p}<0.001)$ and 64.1 percent of the variation of patient delight explained by five factors of emotional attachment chosen for the study. Among the independent variables, 'trust the doctors' is the most influencing variable for patient delight $(\mathrm{t}=10.135 ; \mathrm{p}<0.001)$, which is followed by 'midas' touch ( $\mathrm{t}$ $=9.494 ; \mathrm{p}<0.001)$ and 'confident that doctor cure the disease' $(\mathrm{t}=6.581 ; \mathrm{p}<0.001)$. Happy treatment is the least significant variable for patient delight. Sentiments have a negative and significant relationship with patient delight.

Table .4: Regression analysis - Influence of patient satisfaction and emotional attachment on Patient Delight

Model Summary

\begin{tabular}{|l|r|r|r|r|}
\hline $\mathrm{R}$ & R Square & $\begin{array}{c}\text { Adjusted R } \\
\text { Square }\end{array}$ & F & \multicolumn{1}{c|}{ Sig. } \\
\hline .841 (a) & .708 & .707 & 529.420 & $<0.001$ \\
\hline
\end{tabular}

a Predictors: (Constant), Emotional Attachment, Patient Satisfaction

b Dependent Variable: Patient Delight

Coefficients(a)

\begin{tabular}{|l|r|r|r|r|r|}
\hline & \multicolumn{2}{|c|}{ Unstandardized Coefficients } & $\begin{array}{r}\text { Standardized } \\
\text { Coefficients }\end{array}$ & \multirow{2}{*}{ Sig. } \\
\cline { 2 - 4 } & $\mathrm{B}$ & Std. Error & Beta & 10.624 & .000 \\
\hline (Constant) & .936 & .088 & & 13.466 & .000 \\
\hline $\begin{array}{l}\text { Patient } \\
\text { Satisfaction }\end{array}$ & .476 & .035 & .571 & 7.370 & .000 \\
\hline $\begin{array}{l}\text { Emotional } \\
\text { Attachment }\end{array}$ & .276 & .037 & .313 & \\
\hline
\end{tabular}

a Dependent Variable: Patient Delight

It is clear from the results shown in table. 4 that patient satisfaction and emotional attachment influence patient delight. The regression model explains that 70.7 percent of the variation of patient delight is influenced by patient satisfaction and emotional attachment, and is also statistically significant $(\mathrm{F}=529.420 ; \mathrm{p}<0.001)$. Among the independent variables, patient satisfaction is the most influencing variable for patient delight $(\mathrm{t}=$ 13.466; $\mathrm{p}<0.001)$, which is followed by emotional attachment $(\mathrm{t}=7.370 ; \mathrm{p}<0.001)$.

\section{Discussion}

In this paper, the relationship between service quality and patient satisfaction in the hospital environment has been examined. The impact of patient satisfaction and emotional attachment on patient delight also observed. Hospital service quality has unique dimensions when compare to other service sectors. This study 
has identified ten variables out of which eight independent variables and two dependent variables relating to the service quality of in-patient care. The independent variables are grouped under human factor and non-human factor. Regression analysis has been carried out to find out which factors influence patient satisfaction and patient delight. The result shows both human factor and non-human factor influence patient satisfaction (Oswald et.al 1998).

Among the human factors, sense of well being is the most influencing variable for patient satisfaction (Ramsaran-Fowder 2008). Professional quality has a least insignificant impact on satisfaction. This shows that patients may not be able to evaluate professional quality because of lack of awareness and knowledge. Besides, core outcome is not the most important dimension in health care quality when compared to 'Fair and equitable treatment' otherwise called as reliability (Ramsaran-Fowder (2008).

Among the non-human factors, administrative procedure is the most influencing variable for patient (Dagger et.al, 2007). If a problem exists in the last encounter, discharge procedure, administrative procedure diminish the overall service perception of inpatients (Reidenbach and sandifer-smallwood 1990). Among the emotional attachment variables, 'trust the doctors' is the most influencing variable for patient delight, which is followed by 'midas' touch. Patient satisfaction had a significant impact on patient delight, than emotional attachment which proves that delight is extreme form of satisfaction (Kumar and Iyer, 2001). The results of regression analysis indicate that all dimensions are found to be significant predictors to patient satisfaction except professional quality and fee.

\section{Conclusion and implications}

In this paper, we theoretically identify and empirically verify the antecedent factors that best discriminate between patient satisfaction and patient delight. The result shows that both human and non human factors affect the service quality perception of health care service. It explains that out of seven dimensions of patient health care service quality five dimensions are significant predictors of patient satisfaction. It is evident that interpersonal attitude, sense of well being, physical evidence, administrative procedure, and reputation contributed significantly to the prediction of patient satisfaction. On the other hand professional quality has the least insignificant and fee has a negative and insignificant relationship with patient satisfaction. It shows that patients and their attendants are not much aware of two dimensions which are important in health care service quality (professional quality and fee structure) since it is difficult to evaluate. However managers can help the patients and attendants to evaluate those dimensions through education and training to professionals. Beyond that, service provider can make the patients feel convenient in terms of transparency in treatment process and fee structure.

The other result shows that midas touch, confident, trust, and happy contribute significantly to the prediction of patient delight. It confirms that the patients and their attendants are delighted when they have midas touch along with confident and trust on their professionals. Besides, our findings suggest that service quality and emotional attachment are the important determinants of patient satisfaction and delight. Managers must constantly strive to delight their patients or provide extreme satisfaction through higher levels of performance on attributes that influence satisfaction (Kumar and Iyer, 2001).

\section{Reference}

[1]. Bitner, M.J. 1990. Evaluating service encounters: The effects of physical surroundings and employee responses. Journal of Marketing, 54: 69-82.

[2]. Camgoz-Akdag and Mosad Zineldin (2010), Quality of health care and patient satisfaction - An exploratory investigation of the 5Qs model at Turkey, Clinical Governance, An international journal, Vol.15, No.2, pp.92-101.

[3]. Carman, J.M. (2000), "Patient perceptions of service quality: combining the dimensions", Journal of Services Marketing, Vol. 14 No. 4, pp. 337-52.

[4]. Caruana, A. (2002), "Service loyalty: the effects of service quality and the mediating role of customer satisfaction", European Journal of Marketing, Vol. 36 Nos 7/8, pp. 811-28.

[5]. Charon .L. Oswald; Douglas E Turner, Robin L Snipes and Daniel Butler (1998), Quality determinants and hospital satisfaction, marketing health services, Vol.18, No.1, pg.19-22.

[6]. Chiu, H. and Lin, N. (2004), "A service quality measurement derived from a theory of needs", The Service Industries Journal, Vol. 24 No. 1, pp. 187-204.

[7]. Dagger, Sweeney, Johnson, (2004), “A Hierarchical Model of Health Service Quality - Scale Development and Investigation of and Integrated Model”, Journal of Service Research, Vol. 10, No. 2, pp. 123-142.

[8]. Duggirala, D., Rajendran, C. and Anantharaman, R.N. (2008), "Patient perceived dimensions of total quality service in healthcare", Benchmarking: An International Journal, Vol. 15 No. 5, pp. 560-83.

[9]. Evans, S. \& A.D. Burns (2007), An investigation of customer delight during product evaluation: Implications for the development of desirable products. Proceedings of the Institution of Mechanical Engineers, Part B: Journal of engineering Manufacture, 786, 16251640 .

[10]. Gregory N. Stock, Christopher McDermott, (2011) "Operational and contextual drivers of hospital costs", Journal of Health Organization and Management, Vol. 25 No.2, pp.142 - 158Gro"nroos, C. (1982), Strategic Management and Marketing in the Service Sector, Swedish School of Economics and Business Administration, Helsinki.

[11]. Gro"nroos, C. (1990), Service Management and Marketing, Lexington Books, Lexington, MA. 
[12]. Hong, S.C. and Goo, Y.J.J. (2004), “A causal model of customer loyalty in professional service firms: an empirical study", International Journal of Management, Vol. 21 No. 4, pp. 531-41.

[13]. Jayesh P. Aagja, Renuka Garg, (2010) "Measuring perceived service quality for public hospitals (PubHosQual) in the Indian context", International Journal of Pharmaceutical and Healthcare Marketing, Vol. 4 No.1, pp.60 - 83

[14]. Kara, Lonial, Tarim, Zaim, (2005), "A Paradox of service quality in Turkey: The seemingly contradictory relative importance of tangible and intangible determinants of service quality", European Business Review, Vol. 17, No. 1, pp.5-20.

[15]. Koch, Hugh; White, Charles and Chan, Charles (1992), Quality in Hong Kong's hospital services: senior executive views, International journal of health care quality assurance, Vol.5, No.2, pg.4-6.

[16]. Kumar, A. \& R. Iyer (2001). Role of interpersonal factors in delighting customers. Marketing Management Journal, Vol.11, No.1, 49-57.

[17]. Marley, Collier, Goldstein, (2004), "The Role of Clinical and Process quality in Achieving Patient Satisfaction in Hospitals", Decision Sciences, Vol. 35, No. 3, pp. 349-369.

[18]. Massaro, R. (2003), "Investing in patient safety: an ethical and business imperative", Trustee, Vol. 56 No. 6, pp. 20-3.

[19]. Naresh K. Malhotra, Francis M. Ulgado, James Agarwal, Imad B. Baalbaki, (1994) "International Services Marketing: A Comparative Evaluation of the Dimensions of Service Quality between Developed and Developing Countries", International Marketing Review, Vol. 11 No. 2, pp.5 - 15

[20]. Licata, Mowen, Gowtam (1995), "Diagnosing Perceived Quality in the Medical Service Channel - Marketing Lens Model brings complex exchanges into sharper focus", Journal of Health Care Marketing, Vol. 15, No. 4, pp. 42-49.

[21]. Padma.P, Rajendran.C, Sai.P, (2009), "A Conceptual framework of service quality in healthcare - Perspective of Indian patients and their attendants", Benchmarking: An International Journal, Vol. 16, No. 2, pp. 157-191.

[22]. Radhika, V., Assaf, R.R. and Al-Assaf, A.F. (2007), "JHQ 197 making patient safety and quality improvement act of 2005 work", Journal for Healthcare Quality, National Association for Healthcare Quality, available at: (accessed).

[23]. Ramsaran-Fowdar, (2008) "The relative importance of service dimensions in a healthcare setting", International Journal of Health Care Quality Assurance, Vol. 21 No.1, pp.104 - 124.

[24]. Reidenbach, Smallwood, (1990), "Exploring Perceptions of Hospital Operations by a Modified SERVQUAL Approach", Journal of Health Care Marketing, Vol. 10, No. 4, pp. 47-55.

[25]. Rohini, R. and Mahadevappa, B. (2006), "Service quality in Bangalore hospitals - an empirical study", Journal of Services Research, Vol. 6 No. 1, pp. 59-85.

[26]. Rose, R.C., Uli, J., Abdul, M. and Ng, K.L. (2004), "Hospital service quality: a managerial challenge", International Journal of Health Care Quality Assurance, Vol. 17 No. 3, pp. 146-59.

[27]. Scotti, Harmon, Behson \& Messina (2007), "Links among high-performance work environment, service quality, and customer satisfaction: An extension to the healthcare sector", Journal of Healthcare Management, Vol.52, No.2, pp.109-125.

[28]. Shabbir, Kaufmann, Shehzad (2010), "Service quality, word of mouth and trust: Drivers to achieve patient satisfaction", Scientific research and Essays, Vol. 5, No. 17, pp. 2457-2462.

[29]. Tomes, A.E. and S. Chee Peng Ng (1995), 'Service Quality in Hospital Care: The Development of an In-patient Questionnaire', International Journal of Health Care Quality Assurance, Vol. 8, No.3, pp. 25-33

[30]. Yang.C.C, (2011), "Identification of customer delight for quality attributes and its applications", Total Quality Management, Vol. 22, No.1, pp 83-98. 